DOI: $10.17516 / 1997-1370-0692$

УДК 332.12:339.138

\title{
Methodological Approach to Forming Criteria for Selecting Food Products for Territorial Branding
}

\author{
Tatiana G. Butovaa , Evgenia A. Demakova ${ }^{a}$, \\ Svetlana L. Ulinaa, Olga L. Egoshinaa, Sergey I. Mutovin ${ }^{a, b}$ \\ and Elena P. Danilina*c \\ aSiberian Federal University \\ Krasnoyarsk, Russian Federation \\ ${ }^{b}$ Scientific Research Institute of the Federal Penitentiary System \\ Moscow, Russian Federation \\ ${ }^{c}$ Krasnoyarsk State Medical University \\ named after Prof. V.F. Voino-Yasenetsky \\ Krasnoyarsk, Russian Federation
}

Received 16.10.2020, received in revised form 18.11.2020, accepted 19.11.2020

\begin{abstract}
Modern trends in consumer behaviour and the new business environment in Russian regions and territories focused on local food production have led to increased attention to territorial branding. At the same time, there are virtually no scientific justifications for territorial branding of food products, which has resulted in a lack of methodological recommendations for product branding by local producers and, consequently, in the inefficient practical solutions as regards territorial branding concepts. The lack of a territorially relevant definition of product branding and criteria for selecting food products for branding turned the authors to their own interpretations based on theoretical research. The testing of the methodical approach coupled with empirical research provided evidence of the correctness of the approach selected and the criteria for consumers' preferences in choosing food products, in particular, certain groups of food products manufactured in Krasnoyarsk.
\end{abstract}

Keywords: territorial branding, product branding of territories, food branding, criteria for food preferences, methodology for selecting food criteria for territorial branding.

The project "Concept and models of product branding of the macroregion "Yenisei Siberia" was funded by Krasnoyarsk Regional Fund of Science.

Research area: economy.

\footnotetext{
(C) Siberian Federal University. All rights reserved

* Corresponding author E-mail address: tbutova@sfu-kras.ru, evdemakova@ya.ru,graffity6@ya.ru, egoshina-ol@ya.ru, smutovin@sfu-kras.ru, danjuly@rambler.ru
} 
Citation: Butova, T.G., Demakova, E.A., Ulina, S.L., Egoshina, O.L., Mutovin, S.I., Danilina, E.P. (2020) Methodological approach to forming criteria for selecting food products for territorial branding. J. Sib. Fed. Univ. Humanit. Soc. Sci., 13(11), 1880-1892. DOI: 10.17516/1997-1370-0692.

\section{Introduction}

The creation of territorial branding concepts in Russia has fostered the development of practical tools for their realisation, mainly for brand promotion. This trend is observed in the practical actions of manufacturers, territories and authorities. For example, the Federation Council, voicing the needs of the regions, is looking for new incentives for the development of the constituent entities of the Russian Federation, which have become more considerate to identifying regional brands, their subsequent registration and promotion (Subjects of the Russian Federation, 2019). However, the analysis of scientific publications in the field of empirical research has shown that these are mainly national and urban brands that have been included in this list. Meanwhile, the Russian Federation has as many as 85 subjects and 536 districts, and 1817 municipal districts where food production is located (List of Russian regions, 2020). The lack of knowledge concerning development of practical procedures for creating local brands has itensified empirical research in the area of local area branding.

Today, a plenty of countries are strengthening their geobrands on international and national markets by marking the place of manufacture of local products. Manufacturing companies, in turn, emphasise their belonging to the particular countries, bringing about a phenomenon called "the country of origin effect" (National commodity brands, 2020). Increasing attention to local brands in Russia and abroad (Demakova, 2020, Stoklasa, Starzyczna, 2016, Zenker, 1015) allows us to speak about spatial expansion of the phenomenon and "the place of production effect". This trend will continue, as in Russia the obligatory marking of the place of production has been legislated in the new article "Geographical Indication and Marking of Origin of Goods" of the Civil Code (Civil Code of the Russian Federation, 2020) The new legislation in the area of branding stimulates practical actions to popularise local brands of local territories.

The increasing share of food in consumer spending as a result of the economic crisis, declining living standards and the coronavirus pandemic have furthered the research aimed at finding tools to support local demand for food from local producers in order to improve living standards and support the socio-economic development of the territories, which increases focus on the process of branding local food products within the concepts of territorial branding.

It should be noted that not only economic problems, but also changes in consumer behaviour (the use of food made only by local producers as a new principle in the food behaviour of the population) have brought on rational nutrition, one of whose manifestations is the growing importance of local food in the eating habits of the population, called locavore. The term implies eating only products manufactured or grown locally, i.e. in the area where the population lives, because these foodstuffs are useful and natural (Nechaev, 2016).

The facts described above illustrate the need to change the practices of local food producers, who have to switch to production of such commodities the sustainable demand for which is caused by territorial branding tools. However, the lack of scientifically based methodological support for commodity branding tools hinders their effective application.

Changing the vectors of research in territorial branding and shifting the focus of empirical research to local food branding are now urgent tasks in this area of knowledge.

\section{Methodological framework}

The studies conducted by the authors are targeted at substantiating the methodological approach to creating a system of criteria for selecting food products to develop territorial branding programmes. 
The theoretical purposes of the present research are, first, to clarify the essence of the basic concept "branding" in order to formulate the concept of such categories as "product branding of territories" and to define its difference from the general concept of "branding of territories" (product branding is the part of the structure of territory branding), and second, to specify the methodology of the study.

Development of a methodological approach to the selection of criteria for choosing food products for territorial branding is based on the scientific methodology of the study, relevant target audience of the territory brand - the population as end consumers of food products (Zenker, 2015). Content analysis of publications showed that the most relevant to the subject of the study methodology is the theory of consumer behaviour, which describes factors affecting consumer demand, factors and criteria for selecting goods (Atilgan et al., 2015, Golubovskaia, 2013, Domnin, 2009). Yet, some authors offer other theories, such as causation theory (Chebat, Michon, 2003), to investigate factors influencing consumer choice of goods.

As a conceptual approach to the study, the authors used a value-based approach, treating the brand as value (Domnin, 2009, Osterwalder, 2020, Repina, 2013).

There is steady search for an integrated characteristic of the sought-after food value to ensure sustainable demand for food products, which is defined as "quality" (Chebat, Michon, 2003, Tajik et al., 2016) unlike clothing and footwear, perfume and other prestigious luxury goods for which the value is treated wider and quality is a self-evident attribute.

The authors used desk review and field methods to collect information. Desk review was a comparative analysis of publications to determine approaches to the essence of basic concepts for the territory branding. Offline and online surveys were used as field studies. Online surveys were conducted using Google Forms in order to identify criteria for consumer preferences for confectionery products, brands of sweets and candies sold on the local market in Krasnoyarsk, and consumer satisfaction with the characteristics of "Kraskon" confec- tionery, "Kraskon" being a Krasnoyarsk manufacturer of confectionery products.

The offline survey was conducted using a targeted questionnaire in order to determine the attitude towards food brands of local producers in the Krasnoyarsk Krai and quality factors as criteria for selecting food products in general and food products of local producers. A sample was formed based on the theory of generation with the method of grouping consumers who are food buyers (Astashova, 2014, Butova et al., 2020). The sample of respondents was formed as a targeted deterministic sample, taking into account the practice of market research in the distribution of the share of acceptable number of respondents from the urban population. This method extrapolates on the respondents the behaviour patterns characteristic of certain types of generations (Malhotra, 2002). The offline survey of respondents was processed using the IBM SPSS Statistics license software.

This research methodology founded upon the synthesis of theoretical and empirical studies made it possible to justify the methodological approach 1) to creating a system of criteria for selecting food products for territorial branding, 2) to its testing. On this basis there was formed a reference model of common criteria for selecting food products for branding and a list of specific criteria for selecting brands of confectionery products.

\section{Results}

The creation of a system of criteria for selecting food products for territorial branding requires not only theoretical rationalisation of the criteria, but also, as a comparative analysis of publications has shown, the definition of the concepts used. This is necessary due to the fact that branding and brand promotion are often used as synonyms (Kotler, Keller, 2015) and this approach is extended to branding and brand promotion of the territories (Cleave, 2016, Loguntsova, 2017, Starov, 2015); there is no generally accepted definition of the concepts under study not only in foreign publications but also in Russian sources despite the availability of regulatory documents, industry guidelines and documents accompanying territorial branding concepts. 
In addition, the conceptual apparatus relevant to the commodity aspect of territorial branding is practically not studied in theoretical works, which leads to the problem of inconsistency in regulatory and methodological documents and complicates empirical studies. This has led to the need for theoretical research into the relevant conceptual apparatus, on the basis of which the authors have made refined definitions of the concepts critical for empirical research.

In order to define the concept of "product branding of the territory", we analysed the publications of some authors who use the concept but do not define its essence. They regard the product branding of regional product trademarks within the framework of national branding (Kavaratzis et al., 2005), based on the interaction of regional authorities, manufacturers, retail chains and the public (Stoklasa, Starzyczna, 2016), and rested on product branding measures (Alekseev, 2009).

Supporting the definition of territorial branding as the process of creating a product brand capable of becoming a regional brand with a focus on the place of production (Tajik et al., 2016), the authors proposed a more precise definition of "product branding of the territory" as the process of creating product brands of local manufacturers in the territorial branding structure. Product branding as a process is a set of consistent actions aimed at creating a product brand of the territory with the indicated place of production. The creation of product branding of the territory is the selection of trademarks of products manufactured by local producers in the territory and their transformation into a brand. The selection of potential brands of products to be promoted must be based on certain criteria.

Transforming product branding into an effective tool for implementing the territorial branding concepts requires methodological support, in particular, methodological guidelines to identify criteria for selecting potential product brands for brand promotion. In our opinion, the lack of methodological guidelines in territorial branding practice is rooted in the lack of unified approaches to defining criteria for selecting brands for brand promotion.
Theoretical studies have shown that a number of criteria have been developed. The most common criteria include recognisability or popularity (Aaker, 2003, Starov, 2015); awareness (Aaker, 2003, Domnin, 2009, Kotler, Keller, 2015, Starov, 2015); perceived brand quality (Aaker, 2011, Spreng, 1996); brand satisfaction (Aaker, 2003, Chiou, Droge, 2006); brand image (Hsieh, Li, 2008); and brand preferences (Domnin, 2009).

However, the application of these criteria in practice generates a number of problems, in particular, the same criteria are proposed for the evaluation of different objects, such as assessment of brand capital (Aaker, 2003, Atilgan et al., 2005, Starov, 2015), estimation of brand success (Starov, 2015), brand position rating (Solov'iova, Afanas'eva, 2013), etc.; low level of consistency also contributes to difficulty in applying the criteria. In the present context, it is needless to say that there are no criteria relevant to territorial brands, which prevents their use in the process of creating a list of food brands for territorial branding. There are separate studies describing the criteria for assessing regional brand advantages (Stoklasa, Starzyczna, 2016). Still, most often criteria are proposed without any adaptation to territorial brands.

This has culminated in the development of an empirically-based methodological approach to choosing the criteria for selecting food products from local manufacturers for territorial branding, the aim of which is to propose relevant criteria that reflect and measure the quality of products as perceived by consumers. The lack of such criteria for territorial branding entails a decrease in the effectiveness of regional government support for local producers (Demakova, 2019).

The need for scientific verification of the criteria lies in the fact that unjustified criteria can distort the results and lead to the selection of products that do not correspond to the real attitude of consumers to food brands, which spurs to reduced demand or even no demand at all for these products.

The designation of quality as the main characteristic of foodstuffs determined the authors' choice of this category as the object 
for evaluation by consumers when they choose food products. The obvious and indispensable point is that the branding process will be useless and meaningless if poor quality food products are offered as potential brands.

In order to identify consumer values related to their perception of food quality, which influence their choice of products and which can be used as criteria for selecting products for branding based on the theory of consumer behaviour, a preference criterion was selected (Domnin, 2009) and then a factor analysis was carried out to systemise consumer preferences for factors characterising product quality $(\mathrm{Bu}-$ tova et al., 2020).

On the basis of the results of the factor analysis, we grouped consumer preference criteria for selecting food products based on territorial principles. The linchpin was the general values of consumers regardless of the place of production and local values of consumers, taking into account the fact that products were produced in the certain place:

Group 1 - system of criteria for consumers' food preferences based on common consumer values;

Group 2 - system of criteria for consumers' food preferences of local producers based on the local values of consumers.

Following on from a factor analysis, an integrated model of consumer preferences for food products from local producers was developed (Butova, 2020). It establishes links between general consumer preferences criteria and local food preferences criteria (Table 1).

The authors propose consumer food preference criteria as a basis for building a system of criteria for selecting food products from local producers for territorial branding.

Nevertheless, the system of consumer preference criteria is quite extensive and difficult to evaluate, which involves prioritizing criteria based on determining the significance of criteria for consumer choice. The significance of the consumer preference criteria for 6 groups of generations (Butova, 2020) was calculated as the average share of food products from 13 product groups in the market basket, for which this criterion was the preferred one. The significance of the preference criteria was set out by the share of foodstuffs purchased on the basis of these criteria, and was calculated on the basis of three groups of integrated factors (Fig. 1).

Calculation of the significance of the preference criteria enabled determining the places of the consumer preference criteria and systemising the criteria in accordance with them, with the method of rating used to assess the significance of indicators for brands (Malhotra, 2002) (Table 2).

Table 1. System of consumer preferences in selection of local food products

\begin{tabular}{|l|l|l|}
\hline \multicolumn{1}{|c|}{$\begin{array}{c}\text { Groups of integrated factors } \\
\text { of consumer preferences }\end{array}$} & \multicolumn{1}{|c|}{ General criteria of preferences } & \multicolumn{1}{c|}{ Local criteria of preferences } \\
\hline 1. 1. Consumer evaluation of quality & $\begin{array}{l}\text { 1.Appearance, colour, texture } \\
\text { 2. Taste, smell } \\
\text { 3. Natural ingredients } \\
\text { 4. Packaging exterior }\end{array}$ & $\begin{array}{l}\text { 1.Ratio between price and quality } \\
\text { 2. Personal commitment } \\
\text { 3. Commitment of family members } \\
\text { 4. Packaging exterior }\end{array}$ \\
\hline 2. Promising quality & $\begin{array}{l}\text { 1.Marking } \\
\text { 2.Shelf life } \\
\text { 3. Usefulness } \\
\text { 4. Information signs }\end{array}$ & $\begin{array}{l}\text { 1.Environmental friendliness } \\
\text { 2.Safety } \\
\text { 3. Guaranteed quality }\end{array}$ \\
\hline 3. Reliability & $\begin{array}{l}\text { 1.Popularity of a producer } \\
\text { 2. Goodwill of a producer }\end{array}$ & $\begin{array}{l}\text { 1.Place of production } \\
\text { 2.Popularity and goodwill of a local } \\
\text { producer } \\
\text { 3. Popularity and goodwill of places } \\
\text { of production }\end{array}$ \\
\hline
\end{tabular}

Made according to the results of the authors' study. 


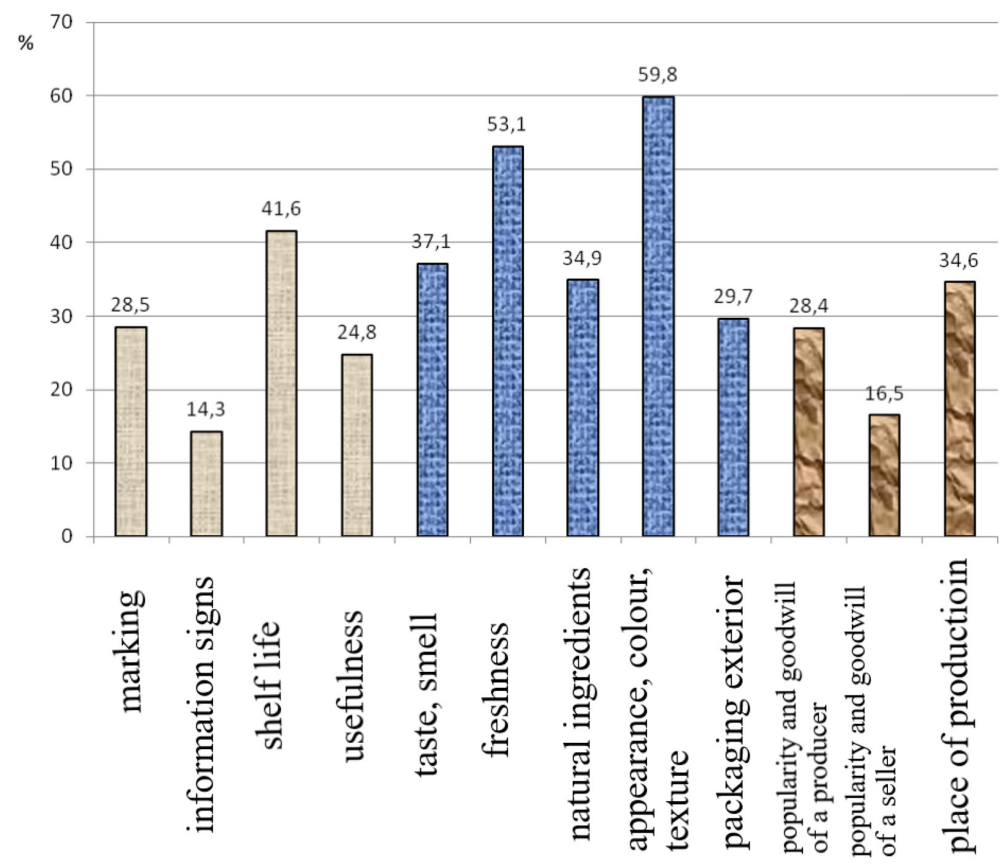

Fig. 1. Share of food products purchased by consumers of all generation groups based on preference criteria

- promising quality;

Table 2. Rating assessment of consumer preference criteria for the selection of local food products

\begin{tabular}{|l|c|c|}
\hline \multicolumn{1}{|c|}{ Preferences criteria } & Share of food products, $\%$ & Place in the rating \\
\hline Appearance, colour, texture & 60 & 1 \\
\hline Freshness & 53 & 3 \\
\hline Shelf life & 42 & 4 \\
\hline Taste, smell & 37 & 5 \\
\hline $\begin{array}{l}\text { Natural ingredients } \\
\text { Place of production }\end{array}$ & 35 & 6 \\
\hline Packaging exterior & 30 & 7 \\
\hline $\begin{array}{l}\text { Popularity and goodwill of a producer } \\
\text { Marking }\end{array}$ & 29 & 9 \\
\hline Usefulness & 26 & 9 \\
\hline Popularity and goodwill of sellers & 17 & 10 \\
\hline Information signs & 14 & \\
\hline
\end{tabular}

Made according to the results of the authors' study.

An analysis of the places of this or that preference criteria in the rating identifies those criteria that should be selected from the list as priority for selecting food products for territorial branding.
It was found that the effectiveness of territorial branding is determined by the coincidence of consumers' real values demonstrated in their preferences for products and the val- 
ues declared by the product brand (Repina, 2013).

For this purpose, consumers need clear and accessible criteria on the basis of which they can evaluate the quality characteristics of products and make their own choices when purchasing. Seemingly, such consumer choice factors as "appearance, colour and texture" $\left(1^{\text {st }}\right.$ place in the ranking), "freshness" ( $2^{\text {nd }}$ place) and "shelf life" ( $3^{\text {rd }}$ place), which consumers can evaluate on their own, must be included in the list of criteria.

Apart from this, the list must contain criteria relevant to territorial brands. An analysis of the results of empirical studies of consumer behaviour in the selection of food products in Krasnoyarsk showed that in the group of factors "reliability of quality" the maximum significance is shown by the criterion "place of production" $\left(5^{\text {th }}\right.$ place in the rating), although there is a differentiation of its significance for different groups of generations $-30 \%$ of such products are chosen by consumers from the group of young women and $42 \%$ of such products - by the group "middle-aged women". The criterion "popularity and goodwill of a producer", which many authors call trustworthy for the choice of products, was ranked $7^{\text {th }}$ in the rating for food products, inferior to the criterion "place of production". However, the criterion "popularity and goodwill of a producer" is important, which conditions its inclusion in the list of criteria for selecting food products for territorial branding.

Based on the results of testing the methodological approach, the authors define the following criteria for selecting food products for territorial branding: "appearance, colour and texture"; "freshness"; "shelf life"; "place of production"; "popularity and goodwill of a producer".

The development of criteria for selecting food products for territorial branding based on preferences for quality factors enhanced $a$ brand model of food products from local producers. These products are in high demand now and show a tendency of stable demand. Taking advantage of this model, it is possible to create a list of local food products sold on local markets.
Hence, to create a list of locally produced foodstuffs for territorial branding, it is necessary to adapt the criteria for individual groups of food products, such as bakery or confectionery ones. The authors think the criteria of recognisability and preference for existing product brands to be the most essential.

The carried out research let us use recognisability and preferences of foodstuffs by consumers in their choice and aspects related to realised demand as criteria for selecting potential brands from the list of brands for territorial branding. Proceeding from how consumers evaluated these criteria, we tested the methodology as part of a study of recognisability and food preferences of 13 groups of food products in the form of a survey of consumers in Krasnoyarsk. The sample included groups of all generations with respondents answering a targeted questionnaire. The analysis of the results helped to identify problems in recognisability and preferences for food brands (Table 3 ).

Of the 13 product groups, only 5 have relatively high recognizability: bakery products; confectionery products; dairy products; meat products; and eggs. The level of consumer recognition of local brands is about $40-50 \%$ for these groups. In the other 8 groups, consumers either cannot remember any trademarks or name individual brands only. The share of brand recognition in these groups is only $20 \%$. The low level of recognition and preference for food products from local producers by Krasnoyarsk consumers may be attributed to the specifics of consumer behaviour in choosing food products and/or the inefficient practice of branding food products by producers.

The presence of different groups of food products with different properties and product characteristics stipulates the need to adapt the criteria to the products of individual product groups. For brand promotion, we suggest choosing general preference criteria that affect demand.

To test the methodology, the authors have chosen confectionery products and used general consumer preference criteria and local criteria - place of production, goodwill of a producer, reputation of sellers, which update the group of "accessibility" factors. 
Table 3. Food trademarks of local producers preferred by Krasnoyarsk consumers (share of consumers in their choice, \%)

\begin{tabular}{|c|c|c|c|c|c|}
\hline $\begin{array}{l}\text { Local } \\
\text { trade- } \\
\text { marks }\end{array}$ & Bakery & Confectionary & Dairy products & Meat & Eggs \\
\hline \multicolumn{6}{|c|}{ Group "Young” (18-25 years old) } \\
\hline Women & $\begin{array}{c}\text { Krasnoyarsky } \\
\text { khleb }(18.6 \%) \\
\text { DiKhleb }(11.9 \%) \\
\text { YarKhleb }(10.2 \%)\end{array}$ & $\begin{array}{c}\text { Kraskon }(20.3 \%) \\
\text { Sladkoe zhel- } \\
\text { anie }(16.9 \%) \\
\text { Komandor's own } \\
\text { production }(5 \%) \\
\text { Krasny Yar's own } \\
\text { production }(5.1 \%)\end{array}$ & 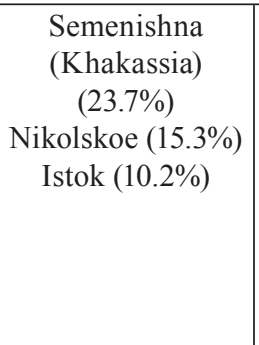 & $\begin{array}{c}\text { Uyar meat } \\
\text { processing } \\
\text { plant }(5.1 \%) \\
\text { "Premier" } \\
\text { butchery }(4.3 \%) \\
\text { KPK (Novosi- } \\
\text { birsk) }(1.6 \%) \\
\text { MaVR }(\text { Kha- } \\
\text { kassia) }(1.7 \%)\end{array}$ & $\begin{array}{c}\text { Barkhatovo (5.1\%) } \\
\text { Zarya }(3.4 \%) \\
\text { Komandor's own } \\
\text { production }(3.4 \%)\end{array}$ \\
\hline Men & $\begin{array}{c}\text { YarKhleb }(15.4 \%) \\
\text { Komandor's } \\
\text { own produc- } \\
\text { tion }(10.3 \%) \\
\text { Krasnoyarsky } \\
\text { khleb }(7.7 \%)\end{array}$ & $\begin{array}{c}\text { Sladkoe zhel- } \\
\text { anie }(17.9 \%) \\
\text { Kraskon }(5.1 \%) \\
\text { Krasny Yar's own } \\
\text { production }(2.6 \%)\end{array}$ & $\begin{array}{c}\text { Semenish- } \\
\text { na }(7.7 \%) \\
\text { Nikolskoe }(5.1 \%) \\
\text { Istok }(2.5 \%) \\
\text { Nazarovskoe } \\
(2.6 \%) \\
\text { Iskra }(2.5 \%)\end{array}$ & $\begin{array}{c}\text { KPK }(2.6 \%) \\
\text { MaVR }(2.6 \%) \\
\text { Uyar meat } \\
\text { processing } \\
\text { plant }(2.6 \%)\end{array}$ & $\begin{array}{c}\text { Barkhatovskoe } \\
(5.1 \%) \\
\text { Selo Maslobo- } \\
\text { evo }(5.1 \%)\end{array}$ \\
\hline \multicolumn{6}{|c|}{ Group "Adults" (26-45 years old) } \\
\hline Women & $\begin{array}{l}\text { Krasnoyarsky } \\
\text { khleb }(13,4 \%) \\
\text { DiKhleb }(6 \%) \\
\text { YarKhleb }(6 \%)\end{array}$ & $\begin{array}{c}\text { Kraskon }(17.9 \%) \\
\text { Sladkoe zhel- } \\
\text { anie }(7.5 \%) \\
\text { Krasny Yar's own } \\
\text { production }(1.5 \%)\end{array}$ & $\begin{array}{c}\text { Nikolskoe }(7.5 \%) \\
\text { Semenishna }(6 \%) \\
\text { Istok }(4.5 \%) \\
\text { Iskra }(4.5 \%)\end{array}$ & $\begin{array}{c}\text { KPK }(6 \%) \\
\text { "Premier" } \\
\text { butchery }(4.5 \%) \\
\text { Berezovsky } \\
\text { meat processing } \\
\text { plant }(3 \%) \\
\text { Province } \\
\text { Solgon }(3 \%)\end{array}$ & $\begin{array}{c}\text { Barkhatovskoe } \\
(13.4 \%) \\
\text { Zarya }(3 \%)\end{array}$ \\
\hline Men & $\begin{array}{c}\text { Krasnoyarsky } \\
\text { khleb }(14.3 \%) \\
\text { YarKhleb }(12.5 \%) \\
\text { Berezovsky bak- } \\
\text { ery plant }(3.6 \%)\end{array}$ & $\begin{array}{c}\text { Kraskon }(28.6 \%) \\
\text { Sladkoe zhel- } \\
\text { anie }(3.6 \%)\end{array}$ & $\begin{array}{c}\text { Semenish- } \\
\text { na }(11.4 \%) \\
\text { Nikolskoe }(8.6 \%) \\
\text { Nazarovskoe } \\
(5.7 \%)\end{array}$ & $\begin{array}{c}\text { Iskra }(5.7 \%) \\
\text { MaVR }(2.9 \%) \\
\text { Uyar meat } \\
\text { processing } \\
\text { plant }(2.9 \%)\end{array}$ & $\begin{array}{c}\text { Barkhatovskoe } \\
(8.6 \%) \\
\text { Selo Maslobo- } \\
\text { evo }(5.7 \%) \\
\text { Zarya }(2.9 \%)\end{array}$ \\
\hline \multicolumn{6}{|c|}{ Group "Middle-aged" (46-65 years old) } \\
\hline Women & $\begin{array}{c}\text { Krasnoyarsky } \\
\text { khleb }(14.3 \%) \\
\text { YarKhleb }(12.5 \%) \\
\text { Berezovsky bak- } \\
\text { ery plant }(3.6 \%)\end{array}$ & $\begin{array}{c}\text { Kraskon }(28,6 \%) \\
\text { Sladkoe zhel- } \\
\text { anie }(3.6 \%) \\
\text { Chernogorsk } \\
\text { confectionary } \\
\text { (Khakassia) } \\
(1.8 \%)\end{array}$ & $\begin{array}{c}\text { Nikolskoe }(12.5 \%) \\
\text { Istok }(8.9 \%) \\
\text { Semenish- } \\
\text { na }(3.6 \%) \\
\text { Iskra }(3.5 \%) \\
\text { Narada }(3.6 \%)\end{array}$ & $\begin{array}{c}\text { Berezovsky } \\
\text { meat processing } \\
\text { plant }(7.1 \%) \\
\operatorname{KPK}(5.4 \%) \\
\operatorname{MaVR}(5.5 \%) \\
\text { Iskra } \\
(5.4 \%)\end{array}$ & $\begin{array}{c}\text { Barkhatovskoe } \\
(19.6 \%) \\
\text { Zarya }(3.6 \%)\end{array}$ \\
\hline Men & $\begin{array}{c}\text { Krasnoyarsky } \\
\text { khleb }(18.5 \%) \\
\text { DiKhleb }(11.1 \%) \\
\text { YarKhleb }(2.6 \%) \\
\text { Komandor's own } \\
\text { production }(3.7 \%)\end{array}$ & Kraskon $(22.2 \%)$ & $\begin{array}{c}\text { Nikolskoe }(14.8 \%) \\
\text { Istok }(11.1 \%) \\
\text { Semenish- } \\
\text { na }(7.4 \%)\end{array}$ & $\begin{array}{c}\text { MaVR }(14.8 \%) \\
\text { KPK }(7.3 \%) \\
\text { Uyar meat } \\
\text { processing } \\
\text { plant }(7.4 \%)\end{array}$ & $\begin{array}{l}\text { Barkhatovskoe } \\
\quad(18.5 \%) \\
\text { Zarya }(11.1 \%) \\
\text { Selo Maslobo- } \\
\text { evo }(3.7 \%)\end{array}$ \\
\hline
\end{tabular}

Made according to the results of the authors' study. 
Tatiana G. Butova, Evgenia A. Demakova... Methodological Approach to Forming Criteria for Selecting Food Products...

Table 4. Consumer preferences in choosing a manufacturer of confectionery brands

\begin{tabular}{|c|c|}
\hline Manufacturers & $\begin{array}{c}\text { Percentage of respondents } \\
\text { who prefer certain confectionery brands, \% }\end{array}$ \\
\hline Kraskon & 44.9 \\
\hline Rossiya & 16.3 \\
\hline Babaevsky & 12.2 \\
\hline Rot Front & 8.2 \\
\hline Krasny Oktyabr & 8.2 \\
\hline Alpen Gold & 6.1 \\
\hline
\end{tabular}

Made according to the results of the authors' study.

Table 5. Structure of customer satisfaction with general quality factors of confectionery products of the "Kraskon" factory

\begin{tabular}{|c|c|}
\hline Factors of satisfaction & Share of respondents indicating satisfaction, \% \\
\hline \multicolumn{2}{|c|}{ Factor “consumer evaluation of quality” } \\
\hline Taste, smell, texture & 71.4 \\
\hline Freshness (evaluation according to expiry date) & 59.2 \\
\hline Natural ingredients "Factor of availability” & 44.9 \\
\hline \multicolumn{2}{|c|}{ Price } \\
\hline Availability at the points of sales
\end{tabular}

Made according to the results of the authors' study.

An online survey of consumers of confectionery products in Krasnoyarsk showed the highest preferences in the group "sweets" to the trademark of the company "Kraskon", which is a local producer of confectionery and pasta products in Krasnoyarsk (Table 4).

The preferences of Krasnoyarsk consumers in the choice of confectionery products from the "Kraskon" factory (Table 3, Table 4) have predicated our choice of the company as the object of research to test our own methodology.

The results of the study have showed that consumers identified a number of characteristics from the group of factors "consumer assessment of quality", namely taste, freshness, shelf life, and also natural ingredients as the main criteria influencing their choice of confectionery products. As for the group of factors "availability", the most popular criteria turned out to be availability at the point of sale and price (Table 5). When asked about the trust in the "Kraskon" factory production, almost all respondents indicated a high level of trust based on the positive reputation of the factory and the length of the factory's operation.

Thus, consumers' identification of the most preferred products from local producers grants an opportunity to select local manufacturers to form a list of their products for brand promotion.

For example, in the group of confectionery products, particularly sweets, we offer the Kraskon factory as a local manufacturer for the city of Krasnoyarsk.

Certainly, with a wide range of products, not all products can become brands. Criteria such as demand levels and consumer preferences tell whether a brand is promising or not for branding. The lack of information on sales of 
Tatiana G. Butova, Evgenia A. Demakova... Methodological Approach to Forming Criteria for Selecting Food Products...

Table 6. Confectionary products - brands of the company "Kraskon"

\begin{tabular}{|c|c|}
\hline Product & $\begin{array}{c}\text { Share of the respondents who consider } \\
\text { this name to be the brand, } \%\end{array}$ \\
\hline Sweets (all) & 8.5 \\
\hline Sweets in boxes & 10.6 \\
\hline Sweets "Kraskosha at the Ball" (Kraskosha na balu) & 19.1 \\
\hline Sweets “Krasnoyark Pillars” (Krasnoiarskie Stolby) & 8.5 \\
\hline Sweets "Autumn bouquet" (Osennii buket) & 4.3 \\
\hline Sweets "Kraskosha in the Evening” (Kraskosha vecherkom) & 4.3 \\
\hline Sweets "Krasnoyarsk in the evening" (Krasnoyarsk vechernii) & 2.1 \\
\hline Sweets “Small Dragon” (Drakosha) & 2.1 \\
\hline Sweets “Tesoro” (Tesoro) & 2.1 \\
\hline Sweets "Sayan" (Saianskie) & 2.1 \\
\hline Sweets “Bagheera” (Bagira) & 2.1 \\
\hline
\end{tabular}

Made according to the results of the authors' study.

individual "Kraskon" sweet and candy brands in public sources has made the authors choose potential brands for brand promotion on the grounds of consumer assessments.

An analysis of the results of a consumer survey about the "Kraskon" factory brands revealed that respondents consider all candies and sweets in boxes to be brands. Consumers chose the following brands from the entire range of sweets (Table 6). The majority of respondents (19.1\%) consider the candies "Kraskosha at the Ball" (in Russian - Kraskosha na balu) and "Krasnoyarsk Pillars" (Krasnoiarskie Stolby) $(8.5 \%)$ to be the brands of the factory's entire range of sweets (Table 6). However, this level of support for these sweet names does not allow us to draw an unambiguous conclusion about whether they are brands and whether they are potential brands for inclusion in the list of confectionery products for brand promotion. In our opinion, economic criteria such as sales level and product life cycle should be assessed as well. Furthermore, market criteria, such as the level and sustainability of market demand, are inherent in selecting food products for territorial branding as potential brands.

Meanwhile, not all well-known and even well-sold trademarks are brands or can become brands. To confirm the hypothesis that the level of recognition of a trademark is a criterion for assigning a trademark to a brand, we measured the percentage of respondents who consider certain names of sweets to be brands.

The results of testing the authors' methodical approach to selecting criteria for the branding of food products by local producers show that the methodical approach is necessary for producers and authorities to make decisions within the framework of territorial branding.

\section{Conclusion}

The relevance of the methodological approach developed by the authors to forming criteria for selecting food products for territorial branding has been proved by the results of theoretical and empirical studies. The selection of criteria for choosing food products for territorial branding is made to assess quality factors on the basis of preference criteria. Then there was built the model of a brand of food products from local producers, which is in high demand by consumers and which guarantees a stable demand for the products of a particular producer.

Identification of problems with territorial branding of food products from local producers was based on the analysis of the methodological approach and incorporated theoretical studies and the criteria for selecting food products. The results of testing the approach showed the low level of recognition and preference for food products from local producers by Krasnoyarsk 
consumers, which proved the practical importance of the authors' approach for application as methodological recommendations for territorial branding.

This confirms that the methodological approach to criteria selection technology can be extended to all products manufactured by local producers.

Moreover, this presents scientists with the task of differentiating research in the area of territorial branding through studies of local product brands. It is vital to study issues relating to consumer behaviour, to make hypotheses and find evidence based on an analysis of consumer behaviour in selecting local product manufacturers and market behaviour of brands on local markets. In the end, it is necessary to investigate the factors of inefficient branding practices of local products and ineffective support from local authorities.

\section{References}

Aaker, D.A. (2011). Brand Relevance Making Competitors Irrelevant. San Francisco: Jossey-Bass, $509 \mathrm{p}$.

Aaker, D.A. (2003). Building Strong Brands. Moscow: Grebennikov Publishing House, 440 p.

Alekseev, A.V. (2009). Brendy produktov pitaniia v sovremennykh usloviiakh [Food brands in modern conditions. In Brand Management, 1, 2-9.

Astashova, Iu.V. (2014). Teoriia pokolenii v marketinge [Theory of generations in marketing]. In Vestnik Iuzhno-Ural'skogo gosudarstvennogo universiteta [Bulletin of South Ural State University], 1, 108-114.

Atilgan, E., Aksoy, S. and Akinci, S. (2005). Determinants of the brand equity: A verification approach in the beverage industry in Turkey. In Marketing intelligence \& planning, 23(3), 237-248.

Butova, T.G., Krotova, I.V., Demakova, E. A., Iakovleva E. Iu., Morgun V.N. (2020). Approaches to Modelling Territorial Brand. In Journal of Siberian Federal University. Humanities \& Social Sciences, 13(4), 464-476.

Chebat, J.C., Michon, R. (2003). Impact of ambient odors on mall shoppers' emotions, cognition, and spending: a test of competitive causal theories. In Journal of Business Research, 56, 529-539.

Chiou, J.S., Droge, C. (2006). Service quality, trust, specific asset investment, and expertise: direct and indirect effects in a satisfaction-loyalty framework. In Journal of the Academy of Marketing Science, 34, 613-627.

Cronin, J.J., Brady, M., Hult, G. (2000). Assessing the effects of quality, value and customer satisfaction on consumer behavior intentions in service environments. In Journal of Retailing, 76 (2), 193-218.

Demakova, E.A., Butova, T.G., Bukharova, E.B., Klimovich, N.V. and Danchenok, L.A. (2020). The role of regional industry standardization in the regional product branding system. In J. Phys.: Conf. Ser. 1515052055

Domnin, V.N. (2009). Predpochteniia brenda - kliuchevoi factor vlianiia na potrebitel'skii spros i rynochnye pokazateli firmy [Brand preferences as a key factor of influence on the consumer demand and market indicators of a firm]. In Brand Management, 3, 130-145.

Esch, F.-R., Langner, T., Schmitt, B. H., Geus, P. (2006). Are brands forever? How brand knowledge and relationships affect current and future purchases. In Journal of Product \& Brand Management, 15(2), 98-105.

Geograficheskoe ukazanie i naimenovanie mesta proiskhozhdeniia tovara. Grazhdanskii kodeks RF [Geographical indication and name of the place of goods production. Russian Civil Code], article 1516. Available at: http://www.consultant.ru/document/cons_doc_LAW_64629/11b7a515e3a042b436472a2a5a679e5cf09f13f8/ (accessed 05 September 2020).

Golubkov, E.P. (1998). Izuchenie potrebnostei [Study of preferences]. In Marketing v Rossi ii za rubezhom [Marketing in Russia and abroad], 5, 11-29.

Golubovskaia, O.L. (2013). Vliianie regional'nykh brendov na potrebitel'skoe povedenie naseleniia: sotsiologicheskii analiz [Influence of the regional brands on the consumer behaviour of the population: 
sociological analysis]. In Abstract of Thesis for Candidate of Sociological Sciences. Penza: Penza State University, $24 \mathrm{p}$.

Hsieh, A.-T., Li, C.-K. (2008). The moderating effect of brand image on public relations perception and customer loyalty. In Marketing intelligence \& planning, 26(1), 26-42.

Kavaratzis, M., Warnaby. G., Ashworth, Gregory J. (2015). Rethinking Place Branding. Comprehensive Brand Development for Cities and Regions. Switzerland: Springer International Publishing, $252 \mathrm{p}$.

Kotler, Ph., Keller, K.L. (2015). Marketing management. St. Petersburg: Piter, 800 p.

Loguntsova, I.V. (2017). Natsional'nye tovarnye brendy v vospriatii territorrii [National product brands in the perception of the territory]. In Marketing territorii [Territorial marketing]. Available at: https://studme.org/167240/marketing/natsionalnye_tovarnye_brendy_vospriyatii_territorii (accessed 24 September 2020).

Malhotra, N.K. (2002). Marketingovye issledovaniia. Prakticheskoe rukovodstvo [Marketing studies. Practical guidelines]. Moscow: Williams, $960 \mathrm{p}$.

Messely, L., Dessein, J., Rogge, E. (2015). Behind the scenes of place branding: unraveling the selective nature of regional branding. In Tijdschrift voor economische en sociale geografie, 7, 291-306.

Nechaev, K. (2016). Pochemu nuzhno est' produkty mestnogo proizvodstva [Why do we need to eat locally produced food?]. Available at: https://ynhe.moneyvam.com/? $p=4174$ (Date of publication: 16 September 2016, accessed 22 September 2020).

Osterwalder, A., Pigneur, Y., Bernarda, G., Smith, A., Papadakos, T. (2020). Razrabotka tsennostnykh predlozhenii. Kak sozdavat' tovary i uslugi, kotorye zakhotiat kupit' potrebiteli [Value Proposition Design: How to Create Products and Services Customers Want]. Moscow: Alpina Publisher, 312 p.

Repina, A.V. (2013). Razrabotka kontseptsii brend marketinga, orientirovannogo na tsennosti [Development of the brand management concept oriented towards values]. In Abstract of Thesis for Candidate of Economical Sciences. St. Petersburg: St. Petersburg State Economical University, 18 p.

Simon, C.J., Sullivan, M.W. (1993). The measurement and determinants of brand equity: a financial approach. In Marketing Science, 12(1), 28-52.

Solov'iova, D.V., Afanas'eva, S.V. (2013). Marketingovyi analiz pozitsii Brenda na rynke: kompleksnyi metod [Marketing analysis of the brand position on the market: integrated method]. In Vestnik Sankt-Peterburgskogo universiteta [Bulletin of St. Petersburg University], 8(1), 31-68.

Sovet Federatsii: sub'ekty RF stali udeliat' bol'she vnimaniia prodvizheniiu regional'nykh brendov [Subjects of the Russian Federation began to pay more attention to the promotion of regional brands] (2019). Available at: https://rupto.ru/ru/news/sovet-federacii-subekty-rf-stali-udelyat-bolshe-vnimaniya-prodvizheniyu-regionalnyh-brendov (accessed 20 March 2019).

Spisok regionov (sub'ektov, oblastei) Rossii [List of regions (subjects, oblasts) of Russia]. (2020). Available at: https://sites.google.com >spisok-regionov-rossii-s-kodamy (accessed 13 March 2020).

Spreng, R.A., Mackoy, R.D. (1996). An empirical examination of a model of perceived service quality and satisfaction. In Journal of retailing, 72(2), 201-214.

Starov, S.A. (2015). Upravlenie brendami [Brand management]. St. Petersburg: Higher School of Management, $500 \mathrm{p}$.

State control over quality and safety (2020). Available at: https://roscontrol.com/community/article/ gosudarstvenniy-kontrol-za-kachestvom-i-bezopasnostyu (accessed 02 September 2020).

Stoklasa, M, Starzyczna, H. (2016). Regional Brand Benefits for Companies - Comparison of 2013 and 2015/6. In Klímová, V., Žítek, V. (eds.) In $19^{\text {th }}$ International Colloquium on Regional Sciences. Conference Proceedings. Brno: Masarykova univerzita, 210-217.

Tajik, A., Gharibi, J., Nategh, T. (2016). Studying indicators related to factor of customers' perception of quality from brand equity and their ranking in the bank of industry and mine. In J. Fundam Appl Sci., 8(3S), 1499-1520.

Upotreblenie pishchi, vyrashchennoi i proizvedennoi v raione prozhivaniia cheloveka [Consumption of food grown and produced in the area where a person lives] (2020). Available at: https://ecology.md/ru/ 
page/upotreblenie-pishhi-vyrashhennoj-i-proizvedennoj-v-rajone-prozhivanie-cheloveka (accessed $02 \mathrm{Sep}$ tember 2020).

Walsh, G., Shiu, E., Hassan, L.M., Michaelido, N., Beatty, S.E. (2010). Emotions, store-environmental cues, store-choice criteria, and marketing outcomes. In Journal of Business Research, 64(7), 737-744.

Zenker, S., Jacobsen, B.P. (2015). Inter-Regional Place Branding Best Practices, Challenges and Solutions. Switzerland: Springer International Publishing, $184 \mathrm{p}$.

\title{
Методический подход к формированию критериев отбора пищевых продуктов для территориального брендирования
}

\author{
Т.Г. Бутова , Е.А. Демакова а, С.Л.Улина, \\ О.Л. Егошина, С.И. Мутовин ${ }^{\text {a, }}$, Е.П. Данилина \\ ${ }^{a}$ Сибирский федеральный университет \\ Российская Федерачия, Красноярск \\ ${ }^{6}$ Научно-исследовательский институт ФСИН России \\ Российская Федерачия, Москва \\ ${ }^{8}$ Красноярский государственныий \\ медицинский университет имени В.Ф. Войно-Ясенецякого \\ Российская Федерация, Красноярск
}

\begin{abstract}
Аннотация. Современные тренды потребительского поведения и новые условия хозяйствования в регионах и территориях России с акцентом на развитие местного производства пищевых продуктов обусловили рост внимания к территориальному брендированию. Между тем вопросам территориального брендирования пищевых продуктов практически не уделяется научного обоснования, что привело к отсутствию методических рекомендаций к товарному брендированию пищевых продуктов местных производителей, а следовательно, и неэффективности практических решений в реализации Концепций брендинга территорий. Отсутствие релевантного к территориям определения понятия товарного брендирования и критериев выбора пищевых продуктов для брендирования позволило авторам на основе теоретического исследования дать свою трактовку понятия «территориальное брендирование пищевой продукции», определить критерии отбора пищевых продуктов для территориального брендирования и предложить эталонную модель бренда пищевого продукта. Апробация методического подхода на основе эмпирического исследования обеспечила доказательность его правильности, а также предпочтений потребителей при выборе пищевых продуктов и, в частности, отдельных групп пищевых продуктов красноярских производителей.
\end{abstract}

Ключевые слова: территориальное брендирование, товарное брендирование территорий, брендирование пищевых продуктов, критерии предпочтений выбора пищевых продуктов, методика отбора критериев пищевых продуктов для территориального брендирования.

Проект «Концепция и модели товарного брендирования макрорегиона «Енисейская Сибирь» профинансирован Красноярским краевым фондом науки.

Научная специальность: экономические науки. 